\title{
Retraction Note: Mountainous atmospheric environment and characteristic products packaging design based on the enhanced technology of Internet of Things
}

\author{
Hongbin Han ${ }^{1}$. Jingjing Zhao ${ }^{1}$
}

Published online: 18 November 2021

(c) Saudi Society for Geosciences 2021

Retraction Note: Arabian Journal of Geosciences (2021) 14: 1819

https://doi.org/10.1007/s12517-021-08070-7

The Editor-in-Chief and the Publisher have retracted this article because the content of this article is nonsensical. The peer review process was not carried out in accordance with the Publisher's peer review policy. Author Jingjing Zhao has not responded to correspondence regarding this retraction. The Publisher has not been able to obtain a current email address for author Hongbin Han.

The original article can be found online at https://doi.org/10.1007/ s12517-021-08070-7.

Jingjing Zhao

jingjingzhao1978@163.com

1 School of Architecture and Artistic Design, Henan

Polytechnic University, Jiaozuo 454000, Henan Province,

China 